\title{
Secreted Metalloproteinase ADAMTS-3 Inactivates Reelin
}

\author{
Himari Ogino, ${ }^{1 *}$ Arisa Hisanaga, ${ }^{1 *}$ (1)Takao Kohno, ${ }^{1}$ Yuta Kondo, ${ }^{1}$ Kyoko Okumura, ${ }^{1}$ Takana Kamei, ${ }^{1}$ Tempei Sato, ${ }^{2}$ \\ Hiroshi Asahara, ${ }^{2}$ Hitomi Tsuiji, ${ }^{1}$ Masaki Fukata, ${ }^{3}$ and Mitsuharu Hattori ${ }^{1}$ \\ ${ }^{1}$ Department of Biomedical Science, Graduate School of Pharmaceutical Sciences, Nagoya City University, Nagoya, Aichi 467-8603, Japan, ${ }^{2}$ Department of \\ Systems BioMedicine, Graduate School of Medical and Dental Sciences, Tokyo Medical and Dental University, Tokyo 113-8510, Japan, and ${ }^{3}$ Division of \\ Membrane Physiology, Department of Molecular and Cellular Physiology, National Institute for Physiological Sciences, National Institutes of Natural \\ Sciences, Okazaki, Aichi 444-8787, Japan
}

The secreted glycoprotein Reelin regulates embryonic brain development and adult brain functions. It has been suggested that reduced Reelin activity contributes to the pathogenesis of several neuropsychiatric and neurodegenerative disorders, such as schizophrenia and Alzheimer's disease; however, noninvasive methods that can upregulate Reelin activity in vivo have yet to be developed. We previously found that the proteolytic cleavage of Reelin within Reelin repeat 3 (N-t site) abolishes Reelin activity in vitro, but it remains controversial as to whether this effect occurs in vivo. Here we partially purified the enzyme that mediates the N-t cleavage of Reelin from the culture supernatant of cerebral cortical neurons. This enzyme was identified as a disintegrin and metalloproteinase with thrombospondin motifs-3 (ADAMTS-3). Recombinant ADAMTS-3 cleaved Reelin at the N-t site. ADAMTS-3 was expressed in excitatory neurons in the cerebral cortex and hippocampus. N-t cleavage of Reelin was markedly decreased in the embryonic cerebral cortex of ADAMTS-3 knock-out (KO) mice. Importantly, the amount of Dab1 and the phosphorylation level of Tau, which inversely correlate with Reelin activity, were significantly decreased in the cerebral cortex of ADAMTS-3 KO mice. Conditional KO mice, in which ADAMTS-3 was deficient only in the excitatory neurons of the forebrain, showed increased dendritic branching and elongation in the postnatal cerebral cortex. Our study shows that ADAMTS-3 is the major enzyme that cleaves and inactivates Reelin in the cerebral cortex and hippocampus. Therefore, inhibition of ADAMTS-3 may be an effective treatment for neuropsychiatric and neurodegenerative disorders.

Key words: Alzheimer's disease; dendrite; protease; proteolysis; Reelin

\section{Significance Statement}

ADAMTS-3 was identified as the protease that cleaves and inactivates Reelin in the cerebral cortex and hippocampus. ADAMTS-3 was expressed in the excitatory neurons of the embryonic and postnatal cerebral cortex and hippocampus. Cleavage by ADAMTS-3 is the major contributor of Reelin inactivation in vivo. Tau phosphorylation was decreased and dendritic branching and elongation was increased in ADAMTS-3-deficient mice. Therefore, inhibition of ADAMTS-3 upregulates Reelin activity and may be a potential therapeutic strategy for the prevention or treatment of neuropsychiatric and neurodegenerative disorders, such as schizophrenia and Alzheimer's disease.

\section{Introduction}

Reelin is a secreted glycoprotein that is essential for the proper organization of brain structures (D’Arcangelo et al., 1995; Sekine

Received Nov. 25, 2016; revised Feb. 6, 2017; accepted Feb. 10, 2017.

Author contributions: H.O., A.H., T.Ko., and M.H. designed research; H.O., A.H., T.Ko., Y.K., K.O., T.Ka., T.S., H.A., H.T., M.F., and M.H. performed research; H.O., A.H., T.Ko., and M.H. analyzed data; H.O., A.H., T.Ko., and M.H. wrote the paper.

This work was supported by KAKENHI (Grants 23123519, 24659036, 26460073, and 16H01366 to M.H. and Grant 26860043 to T.Ko.) and by grants from the (enter for Intellectual Property Strategies (to M.H.) and A-STEP FS Stage (AQ2621606Q) of the Japan Science and Technology Agency (to M.H.), ACT-M (16im0210602h0001) of the Japan Agency for Medical Research and Development (to M.H.), and the Suzuki Memorial Foundation (to T.Ko.). We thank the Wellcome Trust Sanger Institute Mouse Genetics Project and its funders for providing the mutant mouse line

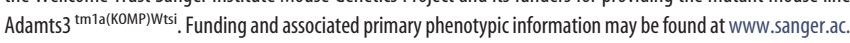
uk/mouseportal. We thank Drs. T. Iwasato (National Institute of Genetics, Shizuoka, Japan), K. Nakajima (Keio et al., 2014). In the adult brain, Reelin modulates neuronal function and synaptic plasticity (Herz and Chen, 2006; Stranahan et al., 2013). Reelin binds to very low-density lipoprotein receptor and apolipoprotein E receptor 2 (D’Arcangelo et al., 1999; Hiesberger et al., 1999) and induces phosphorylation of the intracel-

University, Tokyo, Japan), K. Nishiwaki (Kwansei Gakuin University, Hyogo, Japan), and J. Takagi (Osaka University, Osaka, Japan) for helpful discussion and information.

*H.O. and A.H. contributed equally to this work.

This study was partly funded by Mitsubishi Tanabe Pharma Corporation, but it had no control over the interpretation, writing, or publication of this work.

Correspondence should be addressed to Prof. Mitsuharu Hattori, Department of Biomedical Science, Graduate School of Pharmaceutical Sciences, Nagoya City University, 3-1 Tanabe-dori, Mizuho-ku, Nagoya, Aichi 467-8603, Japan. E-mail: mhattori@phar.nagoya-cu.ac.jp.

DOI:10.1523/JNEUROSCI.3632-16.2017

Copyright $\odot 2017$ the authors $\quad 0270-6474 / 17 / 373181-11 \$ 15.00 / 0$ 
lular protein Dab1 (Howell et al., 1999), which leads to activation or modulation of downstream pathways. Phosphorylated Dab1 is quickly degraded by the ubiquitin-proteasome pathway (Feng et al., 2007). Accordingly, the Dab1 concentration is used as an indicator of the strength of Reelin signaling (Howell et al., 1997; Kohno et al., 2015; Lane-Donovan et al., 2015).

Reduced Reelin activity has been implicated in the pathogenesis of several neuropsychiatric and neurodegenerative disorders, including schizophrenia and Alzheimer's disease (Folsom and Fatemi, 2013; Krstic et al., 2013). Transgenic Reelin expression prevents the manifestation of behavioral phenotypes related to schizophrenia and bipolar disorder induced by chronic corticosterone treatment or by an antagonist to $N$-methyl-D-aspartic acid receptor (Teixeira et al., 2011). Reelin overexpression also rescues the memory deficits observed in Alzheimer's disease model mice by delaying amyloid plaque formation (Pujadas et al., 2014). The injection of Reelin protein into the lateral ventricle of Reelin heterozygous mice rescues their cognitive impairment (Rogers et al., 2013). Adult-specific Reelin knock-out (KO) mice are more vulnerable to amyloid-induced synaptic dysfunction than control mice (Lane-Donovan et al., 2015). Thus, upregulation of Reelin activity may ameliorate certain neuropsychiatric and neurodegenerative disorders.

Reelin protein is cleaved at three sites (Fig. 1A; Lambert de Rouvroit et al., 1999; Kohno et al., 2015). Cleavage at the N-terminal site (N-t cleavage) occurs between Pro1243 and Ala1244 within Reelin repeat 3 (RR3; Koie et al., 2014). Two theories have been proposed regarding the biological significance of $\mathrm{N}$-t cleavage. One theory suggests that $\mathrm{N}$-t cleavage liberates the active fragment from the inactive (or reservoir) full-length Reelin (Jossin et al., 2007; Tinnes et al., 2013). The second theory speculates that $\mathrm{N}-\mathrm{t}$ cleavage results in inactivation. Notably, $\mathrm{N}-\mathrm{t}$ cleavage of Reelin attenuates its ability to induce Dab1 phosphorylation in vitro (Kohno et al., 2009; Koie et al., 2014). Cleavage between RR6 and RR7 (C-t cleavage) is mediated by serine proteases and metalloproteinases (Lambert de Rouvroit et al., 1999; Tinnes et al., 2013; Trotter et al., 2014; Sato et al., 2016). The third cleavage occurs at six residues from the $\mathrm{C}$ terminus and modulates the interaction between Reelin and the neuronal cell membrane (Kohno et al., 2015).

The physiological significance of Reelin processing has been investigated using in vitro systems and recombinant Reelin protein. The main obstacle that has hampered in vivo investigations is the lack of an identification of the protease(s) that cleaves Reelin. We and others showed that a disintegrin and metalloproteinase with thrombospondin motifs 4 (ADAMTS-4) is able to mediate N-t cleavage (Hisanaga et al., 2012; Krstic et al., 2012); however, ADAMTS-4 is not the main protease that mediates N-t cleavage in the culture supernatant (CS) of cerebral cortical neurons (Hisanaga et al., 2012). ADAMTS-5 (Krstic et al., 2012), matrix metalloproteinases (Tinnes et al., 2013), and tissue plasminogen activator (Trotter et al., 2014) are also candidates for mediating N-t cleavage, but whether they cleave Reelin in vivo has not been tested.

Here we identified ADAMTS-3 as the protease that mediates the N-t cleavage of Reelin from the CS of cerebral cortical neurons. Utilizing genetically modified mice, we showed that $\mathrm{N}-\mathrm{t}$ cleavage by ADAMTS-3 is the major mechanism of Reelin inactivation. ADAMTS-3 deficiency decreased Tau phosphorylation and increased dendritic growth and branching. This is the first molecular identification of the protease that negatively regulates Reelin in vivo and may be the first step toward establishing a method to treat neuropsychiatric and neurodegenerative disorders influenced by reduced Reelin activity.

\section{Materials and Methods}

Reagents and antibodies. The following antibodies were purchased: antiReelin G10 (catalog \#MAB5364, RRID: AB_2179313) from Millipore; anti-Reelin AF3820 (catalog \#AF3820, RRID: AB_2253745) from R\&D Systems; anti-Myc (9E10; catalog \#B7554, RRID: AB_439695) and antiactin (AC-15; catalog \#A1978, RRID: AB_476692) from Sigma; rabbit anti-Tbr1 (catalog \#ab31940, RRID: AB_2200219) and rat anti-Ctip2 (catalog \#ab18465, RRID: AB_2064130) from Abcam; goat anti-Brn1 (catalog \#556319, RRID: AB_396358) and anti-phosphorylated Tau (AT8; catalog \#MN1020, RRID: AB_223647) from Thermo Fisher Scientific; and anti-Tau (catalog \#556319, RRID: AB_396358) from BD Biosciences. Rabbit anti-Dab1 was made and affinity purified as described previously (Uchida et al., 2009). The cDNA of mouse ADAMTS-3 was purchased from the Kazusa DNA Research Institute. Anti-ADAMTS-3 antiserum was raised in our laboratory using the following procedure. The cDNA encoding amino acid residues 419-699 of mouse ADAMTS-3 (containing a portion of the metalloproteinase domain, the disintegrin domain, and a portion of the thrombospondin motif) was cloned into pRSET-A (Life Technologies). The protein, which was C-terminally tagged with His6-tag, was expressed in E. coli BL21CodonPlus (Agilent Technologies) and purified with HisTrap FF (GE Healthcare) column chromatography using the AKTA system (GE Healthcare) according to the manufacturer's instructions. The purified protein was used to immunize Japanese white rabbits four times, and the serum was subsequently recovered. For affinity purification, the above cDNA was subcloned into pGEX-4T-1 (GE Healthcare), and the recombinant protein fused to glutathione $S$-transferase (GST) was prepared from transformed E. coli BL21CodonPlus. The GST-fused protein was then purified using GSTTrap FF column chromatography using the AKTA system according to the manufacturer's instructions. The purified protein was coupled with HiTrap NHS-activated HP (GE Healthcare) according to the manufacturer's protocols. The serum was then applied to the column, and antiADAMTS-3 was eluted with $0.1 \mathrm{~m}$ glycine, $\mathrm{pH} 2.7$, and immediately neutralized. A prestained molecular mass marker was purchased from Bio-Rad.

Animals. All experimental protocols were approved by the Animal Care and Use Committee of Nagoya City University and performed according to the guidelines of the National Institutes of Health of Japan. Jcl:ICR and C57BL/6N mice were obtained from Japan SLC. The Reelindeficient reeler mouse (B6C3Fe-a/a-rl) was purchased from The Jackson Laboratory. Knockout-First ADAMTS3 heterozygous mice (Project ID

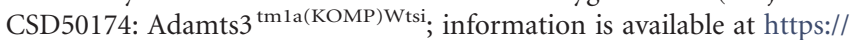
www.komp.org/) were obtained from the Knockout Mouse Project (KOMP) Repository/Welcome Trust Sanger Institute (Skarnes et al., 2011; Bradley et al., 2012). ADAMTS-3 heterozygous mice were backcrossed with Jcl:ICR mice and C57BL/6N mice for biochemical and immunohistochemical analyses, respectively. The results of our study were indistinguishable between the two backgrounds, except for the survival rate of ADAMTS-3 KO mice in postnatal stages. ADAMTS-3 heterozygous mice were crossed with $\mathrm{B} 6-\mathrm{Tg}(\mathrm{CAG}-\mathrm{FLPe}) 36$ mice (number RBRC01834; RIKEN BioResource Center) to excise the promoter-driven selection cassette of the Knock-Out First allele, and the heterozygous offspring (ADAMTS- $3^{\text {flox } /+}$ ) were crossed to generate ADAMTS- $3^{\text {flox/flox }}$ mice. ADAMTS- $3^{\text {flox/flox }}$ mice were crossed with Emx1-Cre $\Delta$ neo mice (RBRC01345, purchased from the RIKEN BioResource Center; Iwasato et al., 2004) to generate ADAMTS- $3^{\text {flox } /+; \text { Emxl-Cre } /+}$ mice, which were then crossed with ADAMTS- $3^{\text {flox/flox }}$ mice to obtain the animals used in the experiments. For all experiments using ADAMTS-3 conditional KO (cKO) mice, the mice were back-crossed with $\mathrm{C} 57 \mathrm{BL} / 6 \mathrm{~N}$ mice.

Genotyping. Genomic DNA preparation (Kohno et al., 2015) and genotyping for the reeler mouse (Koie et al., 2014) were performed as described previously. ADAMTS-3 KO mice were genotyped by PCR (33 cycles at $94^{\circ} \mathrm{C}$ for $30 \mathrm{~s}, 53^{\circ} \mathrm{C}$ for $20 \mathrm{~s}$, and $72^{\circ} \mathrm{C}$ for $15 \mathrm{~s}$ ) using the following primers: G5arm, GAATCCCAGTTTCCTATCAGTGG; G3arm, TTC CCTATAGATAACTAGAGTCTC and CATAAAGTGACCCTCCCAA CAGC. The sizes of the PCR products were $163 \mathrm{bp}$ (WT allele) and $305 \mathrm{bp}$ 
A

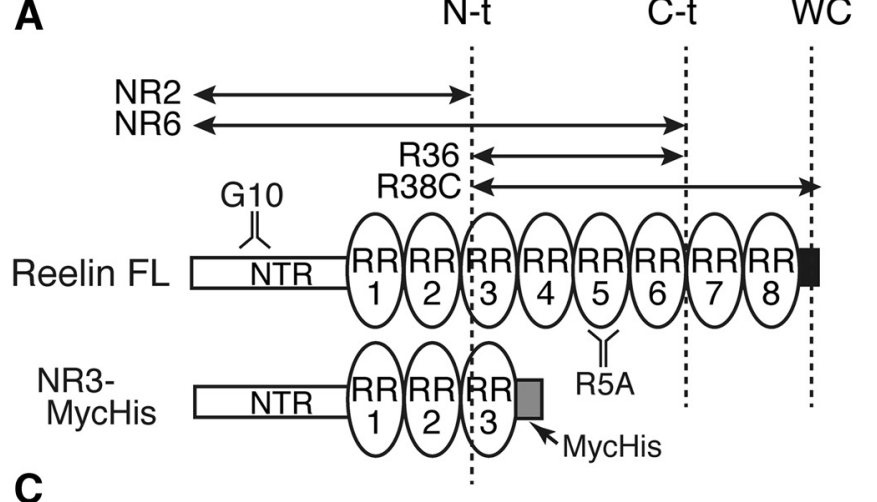

C

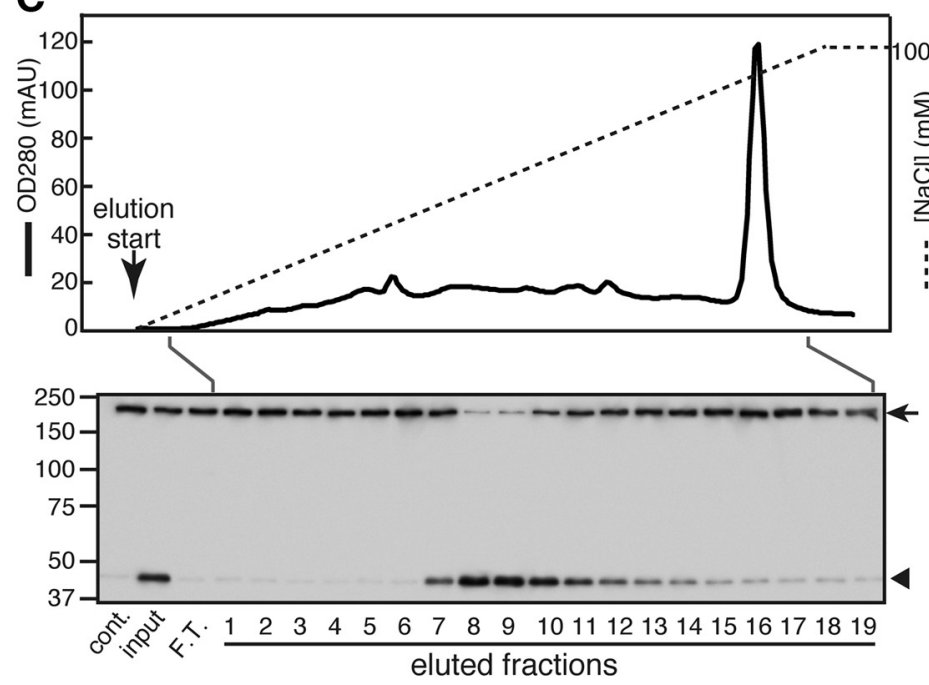

B

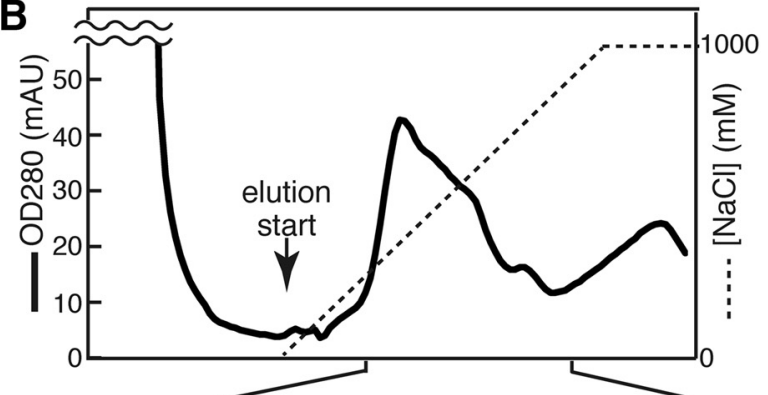

$\mathbf{F}$

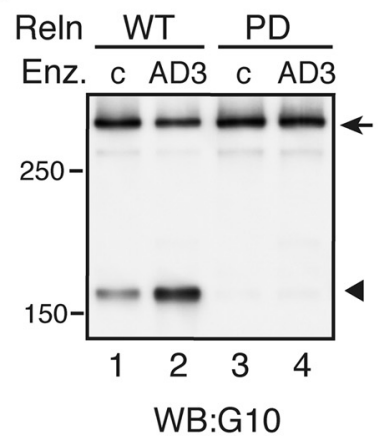

G

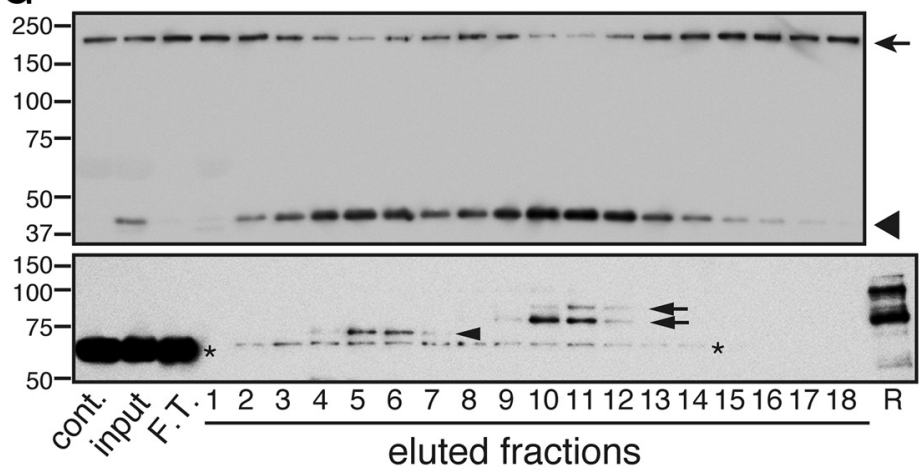

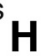

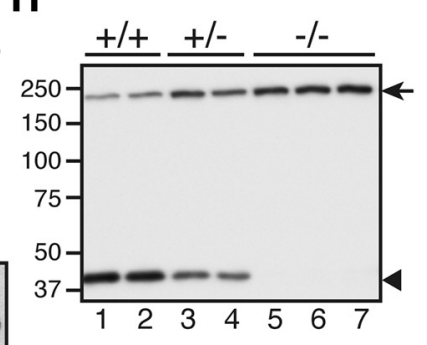

WB: $\alpha$ Myc

Figure 1. Identification of ADAMTS-3 as the protease that mediates the N-t cleavage of Reelin. $\boldsymbol{A}$, Schematic drawing of the Reelin protein, its cleaved products, and the artificial substrate NR3-MycHis. The full-length Reelin protein (Reelin FL) consists of the N-terminal region (NTR), eight tandem Reelin repeats (RR, ovals), and the C-terminal region (CTR, black box). The cleavage sites are indicated by dotted lines. WC, Cleavage within the CTR (Kohno et al., 2015). NR3-Mychis has a Myc epitope and His6-Tag (gray box) at its C terminus. The epitopes of the G10 and R5A antibodies are indicated. $\boldsymbol{B}, \boldsymbol{C}$, Purification of the protease that mediates N-t cleavage using HiTrap Heparin Sepharose column chromatography (B) and Mono $\mathbf{Q}$ column chromatography (C). The top panels show the protein profile (bold line, OD280; broken line, NaCl concentration). The eluted fractions were used for the cleavage assay with NR3-Mychis as a substrate (bottom). NR3-Mychis was incubated with vehicle only (cont.) or an applied fraction (input) for reference. F.T., Flow-through fraction. Positions of the molecular weight markers (in kilodaltons) are shown on the left of the bottom panels. Arrows and arrowheads indicate NR3-Mychis and its cleaved product, respectively. D, SDS-PAGE and silver staining of the eluted fractions from the Mono Q column chromatography shown in C. The asterisk indicates the band containing ADAMTS-3. E, ADAMTS-3 cleaves Reelin at the N-t site. Reelin was incubated with the CS of HEK293T cells transfected with a control vector (left) or the expression vector for ADAMTS-3 (right) for $16 \mathrm{~h}$ at $37^{\circ} \mathrm{C}$. The reaction mixtures were separated by SDS-PAGE and analyzed by Western blotting with the R5A antibody. Positions of full-length Reelin (FL) and cleaved fragments are indicated by arrowheads. Positions of the molecular mass markers (in kilodaltons) are shown on the left. $F$, ADAMTS-3 did not cleave Reelin-PD. Wild-type Reelin (lanes 1 and 2) or Reelin-PD (lanes 3 and 4) were incubated with the CS of HEK293T cells transfected with control vector (c, lanes 1 and 3) or the ADAMTS-3 expression vector (AD3, lanes 2 and 4) for $16 \mathrm{~h}$ at $37^{\circ} \mathrm{C}$. The reaction mixtures were separated by SDS-PAGE and analyzed by Western blotting with the G10 antibody. Positions of Reelin FL and cleaved fragment are indicated by arrow and arrowhead, respectively. Positions of molecular mass markers (in kilodaltons) are shown on the left. G, The elution profiles of N-t cleavage activity and ADAMTS-3 on HiTrap Heparin Sepharose column chromatography matched well. The eluted fractions were used for the cleavage assay (top) or analyzed by Western blotting with the anti-ADAMTS-3 antibody (bottom). The arrow and arrowhead in the top panel indicate NR3-MycHis and its cleaved product, respectively. The arrows and arrowhead in the bottom panel indicate the bands that matched major and minor peaks of $\mathrm{N}$ - $\mathrm{t}$ cleavage activity, respectively. Asterisks indicate nonspecific bands. $\boldsymbol{H}$, The CS of cerebral cortical neurons from ADAMTS-3 KO mice did not cleave Reelin at the N-t site. Primary cerebral cortical neurons were obtained from WT $(+/+)$, ADAMTS-3 heterozygous $(+/-)$, or homozygous $(-/-)$ mice. The CSs were collected $4 \mathrm{~d}$ later and used in the cleavage assay with NR3-Mychis as the substrate. The arrow and arrowhead indicate NR3-Mychis and its cleaved product, respectively. Positions of the molecular mass markers (in kilodaltons) are shown on the left. WB, Western blotting. 
(mutant allele). ADAMTS-3-flox mice were genotyped by PCR ( 35 cycles of $96^{\circ} \mathrm{C}$ for $30 \mathrm{~s}, 54^{\circ} \mathrm{C}$ for $20 \mathrm{~s}$, and $72^{\circ} \mathrm{C}$ for $30 \mathrm{~s}$ ) using the following primers: G5arm, CCATAGTACAACAGAGAGAACGAG; G3arm, GAA ATCTATCCTTGAGCTAGAGC. The sizes of the PCR products were 603 bp (WT allele) and $651 \mathrm{bp}$ (floxed allele). Genotyping for Emx1-Cre (RBRC01345) was performed as described on the RIKEN BioResource Center website.

Partial purification of the protease that mediates $N$-t cleavage of Reelin. The CS (total $880 \mathrm{ml}$ ) was filtered using a $0.4 \mu \mathrm{m}$ filter (Millipore), and $150 \mathrm{ml}$ of the filtrate was used for HiTrap Heparin Sepharose column chromatography using the AKTA system (GE Healthcare). After washing with $10 \mathrm{ml}$ of Buffer A (10 mM Tris- $\mathrm{HCl}, \mathrm{pH} 7.5)$, bound proteins were eluted with a $\mathrm{NaCl}$ gradient $(0-1 \mathrm{M})$ in Buffer $\mathrm{A}$. The flow rate was 0.5 $\mathrm{ml} / \mathrm{min}$ during all procedures. The same experiment was repeated six times. Fractions $(0.5 \mathrm{ml})$ were collected, and an aliquot $(20 \mu \mathrm{l})$ was used for the cleavage assay (Hisanaga et al., 2012). Briefly, a sample was mixed with the artificial substrate NR3-MycHis (Hisanaga et al., 2012), incubated for the indicated times at $37^{\circ} \mathrm{C}$, and analyzed with Western blotting using an anti-Myc antibody. The active fractions were collected, dialyzed against Buffer B (20 mm Tris, pH 8.0), and used for Mono Q column chromatography. The column was washed with $10 \mathrm{ml}$ of Buffer $\mathrm{B}$, and bound proteins were eluted with a gradient of $\mathrm{NaCl}(0-1 \mathrm{M})$ in Buffer $\mathrm{B}$. The eluted fractions were separated using SDS-PAGE, and the gel was stained with a silver staining kit for mass spectrometry (Wako). The bands were excised and used for mass spectrometry.

Mass spectrometry. All protein bands observed in fractions 8 and 9 in Figure $1 D$ were excised from a silver-stained gel, reduced with dithiothreitol, and alkylated with iodoacetamide. Band slices were digested with trypsin (12 $\mu \mathrm{g} / \mathrm{ml}$ ) at $37^{\circ} \mathrm{C}$ overnight and desalted with ZipTip C18 (Millipore). The obtained peptides were then separated via nano-flow liquid chromatography (Paradigm MS4; AMR) using a reverse-phase C18 column. The liquid chromatography eluent was coupled to a nanospray ion source attached to an LCQ Advantage or Fleet mass spectrometer (Thermo Fisher Scientific). For protein identification and semiquantification, we used the score of the SEQUEST algorithm from BioWorks software (Thermo Fisher Scientific).

Immunohistochemistry and RNA in situ hybridization. Embryonic brains were immediately immersed in $4 \%$ paraformaldehyde (PFA) in PBS for $6 \mathrm{~h}$ at $4^{\circ} \mathrm{C}$. Postnatal mice were perfused transcardially with $4 \%$ PFA in PBS. Fixed brains were cryoprotected by sequential immersion in 20 and $30 \%$ sucrose in PBS, embedded in OCT Compound (Sakura Finetek), and quickly frozen on dry ice. The frozen sections were sagittally or coronally sectioned with a thickness of $14 \mu \mathrm{m}$ using a cryostat (CM 1850; Leica Microsystems). Immunohistochemistry was performed as described previously (Kohno et al., 2015). RNA in situ hybridization was performed using digoxygenin (DIG)-labeled probes. The cDNA fragment of nucleotides 270-1028 (759 bp) for Reelin or 1281-2036 (756 bp) for ADAMTS-3 was cloned into pBluescript II SK(-) (Agilent Technologies), and the probes were synthesized using DIG Labeling Mix (Roche). Hybridization was performed at $55^{\circ} \mathrm{C}$ in a buffer containing $50 \%$ formamide (Wako), $2 \times$ SSC $(20 \times$ SSC $=3 \mathrm{M} \mathrm{NaCl}$ and $0.3 \mathrm{M}$ trisodium citrate dehydrate; Wako), $1 \times$ Denhardt's solution, $1 \%$ polyvinylpyroridin K-30 (Wako), 1\% Ficoll PM 400, 10 mM EDTA, $50 \mu \mathrm{g} / \mathrm{ml}$ yeast tRNA (Roche), $0.01 \%$ polyoxyethylene (20) sorbitan monolaurate (Tween 20; Wako), and 5\% dextran sulfate (Sigma). Sections were then washed in $5 \times \mathrm{SSC} / 50 \%$ formamide and $2 \times \mathrm{SSC} / 50 \%$ formamide. Next, sections were treated in a buffer containing $0.5 \mathrm{M} \mathrm{NaCl}, 1 \mathrm{~mm}$ Tris- $\mathrm{HCl}$, pH 8.0, 2 mm EDTA, $0.0005 \%$ Tween 20, and $10 \mu \mathrm{g} / \mathrm{ml} \mathrm{RNaseA}$ at room temperature for $1 \mathrm{~h}$ and washed in TBS containing $0.05 \%$ Tween 20 (TBS-T). After a $1 \mathrm{~h}$ incubation in $2.5 \%$ bovine serum albumin ( $\mathrm{Na}$ calai Tesque) in TBS-T, the sections were incubated with an alkaline phosphatase-conjugated goat anti-DIG Fab fragment (1:1000; Roche) in $2.5 \%$ bovine serum albumin overnight at $4^{\circ} \mathrm{C}$. After washing with TBS-T and NTMT buffer ( $0.1 \mathrm{M} \mathrm{NaCl}, 0.1 \mathrm{M}$ Tris- $\mathrm{HCl}$, pH 9.5, $0.05 \mathrm{M} \mathrm{MgCl}_{2}$, and $1 \%$ Tween 20), the hybridized probes were detected using $0.17 \mathrm{mg} / \mathrm{ml}$ 5-bromo-4-chloro-3-indolyl-phosphate and $0.33 \mathrm{mg} / \mathrm{ml}$ nitro blue tetrazolium in NTMT buffer at room temperature.

Golgi-Cox staining. Golgi-Cox staining was essentially performed as described previously (Datwani et al., 2002). P14 brains were immersed in a Golgi-Cox solution for $3 \mathrm{~d}$, followed by $7 \mathrm{~d}$ in $30 \%$ sucrose. Brains were then sectioned on a VT1000S vibratome (Leica Microsystems) into 160 $\mu \mathrm{m}$ unfixed sections. Sections were incubated in 15\% aqueous ammonium hydroxide (Wako) for 30 min under the fume hood in the dark, followed by $30 \mathrm{~min}$ in Kodafix solution (CosmoBio). After rinsing in distilled water twice, sections were dehydrated with an ethanol series and lemosol and mounted with Softmount (Wako). Layer V neurons with cell bodies located in the lower part of each section were selected from the somatosensory area using a light microscope and $60 \times$ oil-immersion lens. Pictures were taken with a BZ-9000 (Keyence). The primary and secondary dendrite lengths were measured using ImageJ with NeuronJ plugin (National Institutes of Health; RRIDs: SCR_003070 and SCR_00 2074). We counted and measured the length of secondary dendrites that branched from the primary dendrite within $80 \mu \mathrm{m}$ of the soma. All experiments were performed by researchers blinded to the genotypes of the mice.

Skeletal analysis. Whole-mount Alcian blue and Alizarin red S staining of the skeletons was performed as described previously (Miyaki et al., 2010).

Cell culture and transfection. The culturing of human embryonic kidney (HEK) 293T cells (RRID:CVCL_0063), preparation of mouse primary cerebral cortical neurons, transfection of plasmid DNA using Lipofectoamine2000 (Life Technologies), and recovery and preservation of CS were performed as described previously (Nakano et al., 2007). The neurons were cultured in Neurobasal medium (NB) supplemented with 2\% B27 supplement, 50 units/ml penicillin/streptomycin, and $2 \mathrm{~mm}$ L-glutamine (all from Life Technologies). To obtain the starting material for protease purification, the medium was changed to NB with $0.1 \%$ B27 supplement $16 \mathrm{~h}$ after plating and cultured for 3 more days.

Western blotting. Dissected cerebral cortices and hippocampi were homogenized in lysis buffer (20 mm Tris- $\mathrm{HCl}, \mathrm{pH} 7.5,150 \mathrm{~mm} \mathrm{NaCl}, 5 \mathrm{~mm}$ EDTA, $1 \%$ Triton $\mathrm{X}-100,0.1 \% \mathrm{H}_{2} \mathrm{O}_{2}$, and $5 \mathrm{~mm} \mathrm{Na}_{3} \mathrm{VO}_{4}$ ). Insoluble debris was removed by centrifugation (10 $\mathrm{min} ; 13,000 \mathrm{rpm}$ ), and the supernatants were collected. Western blotting was performed as described previously (Kohno et al., 2015). The amount of the NR6 fragment was not quantitated in the postnatal stages because the very low level prohibited reliable results. Images were analyzed with ImageJ and quantified as described previously (Nakano et al., 2007).

Statistical analyses. The statistical data are shown as the mean \pm SEM. To compare three different groups, Tukey's multiple comparison test was used. To compare two different groups, one sample $t$ test was used to compare the mean with the control value, and Student's $t$ test was used to compare the means of two groups. Statistical analyses were performed with Microsoft Excel and Prism (GraphPad Software). Statistical significance was represented as ${ }^{\star} p<0.05,{ }^{* *} p<0.01$, and ${ }^{\star * *} p<0.001$.

\section{Results}

Identification of ADAMTS-3 as the protease that mediates $\mathrm{N}-\mathrm{t}$ cleavage of Reelin

Primary cultures of cerebral cortical neurons secrete a protease that mediates N-t cleavage of Reelin (Lambert de Rouvroit et al., 1999; Kohno et al., 2009; Hisanaga et al., 2012). To determine the identity of the protease, we purified the protein from the CS of primary mouse cerebral cortical neuronal cultures. We optimized the culture conditions to avoid contamination from proteins in the B27 supplement without decreasing the total amount of N-t cleavage activity. The key conditions included the cell concentration, the removal of most of the B27 supplement on the day after plating the neurons, and the culture period. We also took special care to complete the chromatography steps as fast as possible because we observed that the $\mathrm{N}$-t cleavage activity was quickly lost as the purification proceeded or when the protein concentration became low. Therefore, we performed all the purification steps continuously and completed the purification within $40 \mathrm{~h}$.

The CS obtained under these conditions was separated by HiTrap Heparin Sepharose chromatography. The majority of N-t cleavage activity was eluted with $\sim 600 \mathrm{~mm} \mathrm{NaCl}$ (Fig. $1 B$, lanes 
ADAMTS-3, E13.5

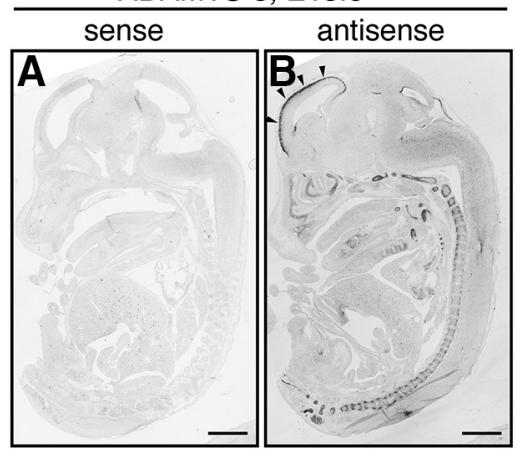

E15.5

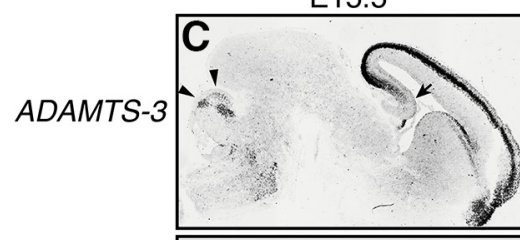

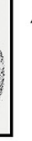
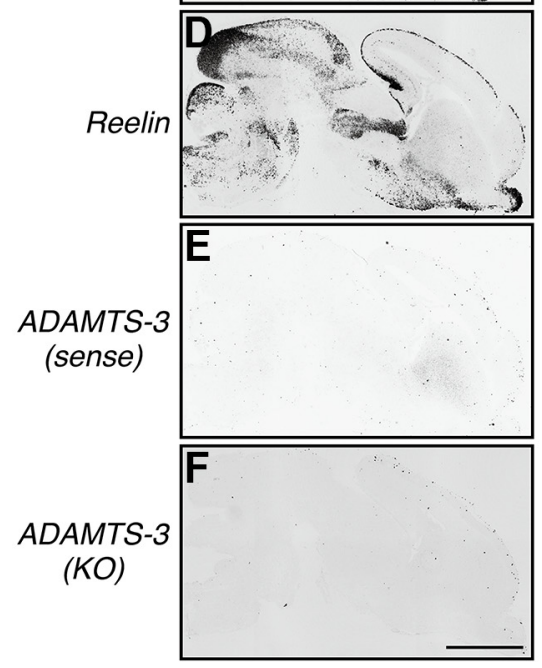
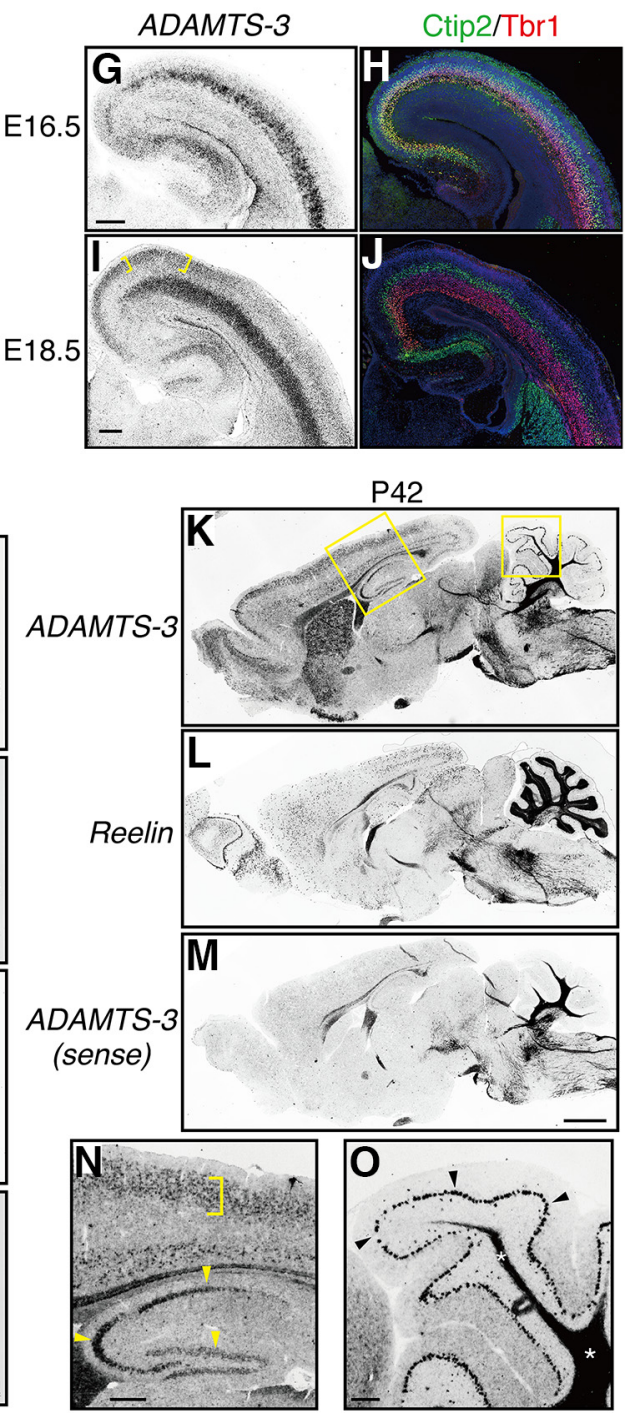

Figure 2. Expression patterns of ADAMTS-3 in the developing and adult brains. $\boldsymbol{A}, \boldsymbol{B}$, In situ hybridization of ADAMTS-3 in the E13.5 whole embryo. Sense $(\boldsymbol{A})$ and antisense $(\boldsymbol{B})$ probes were used. Expression of $A D A M T S-3$ in the cerebral cortex is indicated by arrowheads. $\mathbf{C}-\boldsymbol{F}$, In situ hybridization of E13.5 brain sagittal sections. Antisense probes for ADAMTS-3 (C, $\boldsymbol{F})$ or Reelin (D) were used. In $\boldsymbol{C}$, the hippocampus and cerebellum are indicated by the arrow and arrowheads, respectively. $\boldsymbol{E}$, The sense probe for ADAMTS-3 was used. $\boldsymbol{F}$, The brain from an ADAMTS-3 K0 mouse was used. $\boldsymbol{G}-\boldsymbol{J}$, Coronal sections from E16.5 $(\boldsymbol{G}, \boldsymbol{H})$ or E18.5 $(\boldsymbol{I}, \boldsymbol{J})$ were used for in situ hybridization of ADAMTS-3 $(\mathbf{G}, \boldsymbol{I})$ or for immunostaining $(\boldsymbol{H}, \boldsymbol{J})$ with antibodies against Ctip2 (green) and Tbr1 (red). Nuclei were stained using Hoechst 33342 (blue). Ctip2 and Tbr1 were used as markers for layers V/VI and VI, respectively. In $\boldsymbol{I}$, the upper layers of the medial part of the cerebral cortex are indicated by yellow brackets. $\boldsymbol{K}-\mathbf{0}, \mathbf{I n}$ situ hybridization of the $\mathrm{P} 42$ brain. Antisense probes for ADAMTS-3 $(\boldsymbol{K}, \boldsymbol{N}, \mathbf{O})$ or Reelin $(\boldsymbol{L})$ were used. $\boldsymbol{M}$, The sense probe for ADAMTS-3 was used. The magnified images of boxed areas in $\boldsymbol{K}$ are shown in $\boldsymbol{N}$ and $\boldsymbol{O}$. In $\boldsymbol{N}$, the upper layers of the cerebral cortex and hippocampus are indicated by the yellow bracket and arrowheads, respectively. In $\mathbf{O}$, the Purkinje cell layer is indicated by arrowheads. The asterisks indicate nonspecific signals. Scale bars: $A, B, F, M, 1 \mathrm{~mm} ; G, I, N, \mathbf{O}, 300 \mu \mathrm{m}$.

7-10), and minor activity was eluted with $\sim 400 \mathrm{~mm} \mathrm{NaCl}$ (Fig. $1 B$, lanes 2-4). The main active fractions were collected, dialyzed, and further separated using Mono Q ion exchange column chromatography (Fig. 1C). The $\mathrm{N}$-t cleavage activity was eluted with $\sim 400 \mathrm{~mm}$ $\mathrm{NaCl}$ (Fig. 1C, lanes 7-12). Proteins in the active fractions were separated using SDS-PAGE and stained with silver. All bands that corresponded to the $\mathrm{N}-\mathrm{t}$ cleavage activity were analyzed by mass spectrometry. We found that the $80 \mathrm{kDa}$ band mainly consisted of ADAMTS-3 (Fig. 1D, asterisk). The reported characteristics of ADAMTS-3 (Fernandes et al., 2001; Apte, 2009), including zinc dependency, a requirement for proprotein convertase activity for maturation, molecular weight, and heparin binding, were consistent with those of the protease that mediates N-t cleavage (Hisanaga et al.,
2012). ADAMTS-3 is expressed in the brain (Le Goff et al., 2006). Recombinant ADAMTS-3 secreted from transfected HEK293T cells mediated N-t cleavage but not C-t cleavage (Fig. 1E), and it did not cleave mutant Reelin protein in which Pro1243 was replaced with Asp (Reelin-PD; Koie et al., 2014; Fig. 1F). Therefore, ADAMTS-3 and the protease that mediates $\mathrm{N}-\mathrm{t}$ cleavage in the CS shared similar substrate specificities. The main active fractions from HiTrap Heparin Sepharose column chromatography contained an $80 \mathrm{kDa}$ isoform of ADAMTS-3 (Fig. 1G, lanes 10-12), whereas the minor fractions contained a 70 $\mathrm{kDa}$ isoform (Fig. 1G, lanes 4-7). These isoforms were also found with recombinant ADAMTS-3 (Fig. 1G, lane R). Furthermore, the CS of cerebral cortical neurons from ADAMTS-3 KO mice did not mediate $\mathrm{N}-\mathrm{t}$ cleavage (Fig. $1 H$ ). These results indicated that the N-t cleavage activity in the CS of cerebral cortical neurons was mediated exclusively by ADAMTS-3.

\section{ADAMTS-3 is expressed in neurons that are targets of Reelin}

ADAMTS-3 was strongly expressed in the cerebral cortex and the vertebrae at E13.5 (Fig. 2B). In the brain at E15.5, ADAMTS-3 was strongly expressed in the cortical plate and weakly in the hippocampus and cerebellum (Fig. 2C). This staining distribution was roughly complementary to that of Reelin (Fig. 2D). Little signal was observed for the sense probe (Fig. $2 A, E$ ) or sections from ADAMTS-3 $\mathrm{KO}$ mice (Fig. $2 F$ ), thus confirming the specificity of the obtained signals. Immunostaining of adjacent sections revealed that ADAMTS-3 was expressed mainly in Tbr1-positive neurons at E16.5 (Fig. $2 G, H$ ) and E18.5 (Fig. 2I,J). In addition, ADAMTS-3 was expressed in the upper layers of the medial part of the cerebral cortex at E18.5 (Fig. 2I). In the adult brain, ADAMTS-3 was expressed in many regions (Fig. $2 \mathrm{~K}$ ), including cerebellar Purkinje cells (Fig. 2O). In the adult cerebral cortex, ADAMTS-3 was most strongly expressed in the upper layers of the cortical plate and in the deep layers (Fig. $2 \mathrm{~K}, N$ ) where Reelin expression was also observed (Fig. 2L). Thus, cells expressing ADAMTS-3 significantly overlap with neurons that are targets of Reelin in the brain.

\section{ADAMTS-3 is the major protease that cleaves and thereby downregulates Reelin in the embryonic cerebral cortex} The concentration of NR2 fragments in the cerebral cortex of ADAMTS-3 KO mice was markedly lower than that of the heterozygous or WT mice at E15.5 (Fig. 3A,C) and E18.5 (Fig. $3 B, D)$. Concomitantly, the concentration of the NR6 fragments was increased at both stages (Fig. $3 C, D$ ). The amount of full- 
length Reelin protein (Reelin FL) was increased at E15.5 (Fig. 3C) but not at E18.5 (Fig. 3D). Most Reelin FL was present intracellularly (i.e., in the presecretion fraction), and thus the intensity of the band does not reflect the amount of Reelin FL in the extracellular milieu. Importantly, Dab1 levels were significantly decreased in ADAMTS-3 KO mice both at E15.5 (Fig. $3 A, E$ ) and E18.5 (Fig. $3 B, F$ ), indicating that Reelin activity was augmented in the cerebral cortex of embryonic ADAMTS-3 KO mice. Therefore, ADAMTS-3 is the major protease that cleaves and downregulates Reelin in the embryonic cerebral cortex.

One of the important pathological outcomes of Reelin-Dabl signaling is suppression of Tau phosphorylation (Hiesberger et al., 1999). Thus, we investigated the phosphorylation level of Tau in the cerebral cortex of ADAMTS-3 KO mice. Antiphosphorylated Tau antibody AT8 detected two major bands in WT mice (Fig. $3 G$, top, lanes 1 and 2). In ADAMTS-3 KO mice, these two bands were markedly decreased (Fig. 3G, top, lanes 3 and 4, H,I) with little effect on total Tau (Fig. 3G, middle). Therefore, ADAMTS-3 deficiency is sufficient to decrease Tau phosphorylation.

\section{ADAMTS-3 is not required for neuronal layer formation in the cerebral cortex}

At E18.5, ADAMTS-3 KO mice exhibited the expected Mendelian ratio (57:219). Most ADAMTS-3 KO mice died shortly after birth from an apparent inability to breathe (Fig. 4A). Indeed, ADAMTS-3 KO mice exhibited abnormal rib development, and their rib cages were narrow (Fig. $4 B$ ). The anteroposterior axis of the skull of ADAMTS-3 KO mice was shorter when compared with WT mice (data not shown). Some ADAMTS-3 KO mice survived into adulthood and were fertile, but the shape of their head remained abnormal (Fig. 4C). Therefore, ADAMTS-3 plays an important role in skeletal development during embryonic stages, whereas this protein is dispensable in developed mice.

We immunostained sections of the cerebral cortex of WT and ADAMTS-3 KO mice at E16.5 with the anti-Reelin antibodies AF3820 and 2F3. AF3820 recognizes the N-terminal region of Reelin, and $2 \mathrm{~F} 3$ only recognizes Reelin protein that is not cleaved at the N-t site (Koie et al., 2014). The signals obtained by these antibodies were indistinguishable between WT and ADAMTS-3 KO mice (Fig. 4D). The localization of Dab1 protein was also very similar between WT and ADAMTS-3 KO mice (Fig. 4E). These results indicate that ADAMTS-3 deficiency does not greatly affect the local-
A

E15.5

B
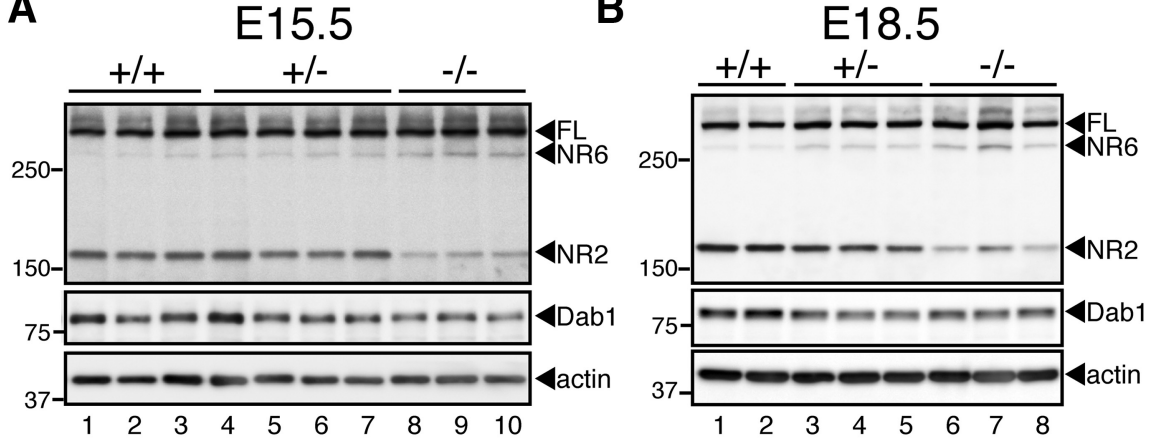

D

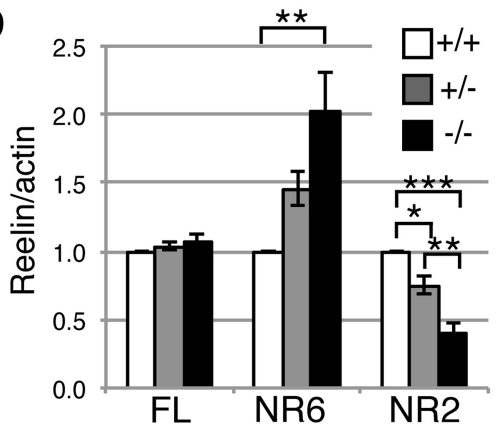

$\mathrm{F}$

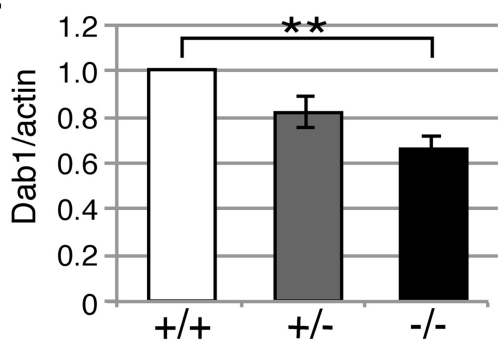

G

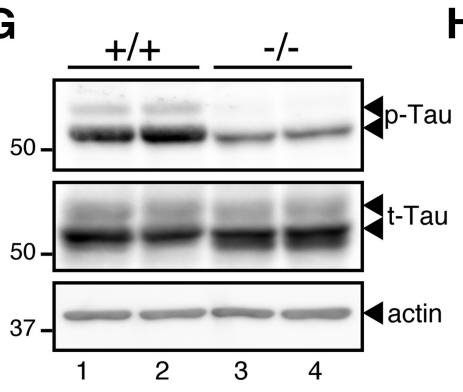

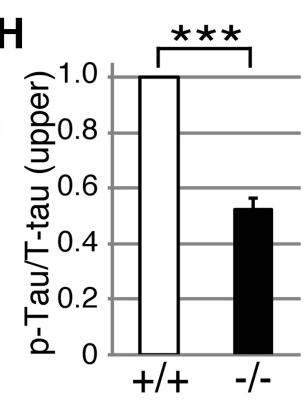

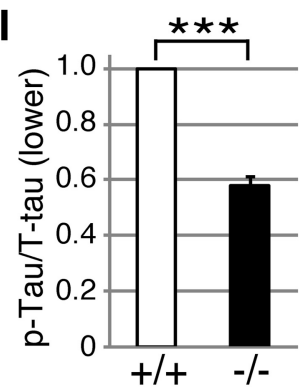

Figure 3. Reelin NR2 fragment, Dab1, and Tau phosphorylation levels are decreased in ADAMTS-3 K0 mice. $\boldsymbol{A}, \boldsymbol{B}$, Western blotting analysis of the cerebral cortex of WT $(+/+)$, ADAMTS-3 heterozygous $(+/-)$, or homozygous $(-/-)$ mice at E15.5 (A) or E18.5 (B) using anti-Reelin (top), anti-Dab1 (middle), and anti-actin (bottom) antibodies. C, D, Quantification of Reelin FL and its cleaved products at E15.5 $(\boldsymbol{C}, n=6)$ and E18.5 $(\boldsymbol{D}, n=5)$. The data are shown as the mean \pm SEM. and were analyzed using Tukey's multiple comparison test. ${ }^{*} p<0.05 ;{ }^{* *} p<0.01 ;{ }^{* * *} p<0.001$. E, $\boldsymbol{F}$, Quantification of Dab1 at E15.5 $(\boldsymbol{E}, n=6)$ and E18.5 $(\boldsymbol{F}, n=5)$. The data are shown as the mean \pm SEM and were analyzed using Tukey's multiple comparison test. ${ }^{* *} p<0.01 ;{ }^{* * *} p<0.001$. G, Western blotting analysis of the cerebral cortex of WT $(+/+)$ or homozygous (-/ -) mice at E18.5 using antiphosphorylated Tau AT8 (top), anti-Tau (middle), and anti-actin (bottom) antibodies. $\boldsymbol{H}, \boldsymbol{I}$, Quantification of phosphorylated Tau. The data are shown as the mean \pm SEM and were analyzed using one sample $t$ test $(n=3) .{ }^{* * *} p<0.001$.

ization of Reelin and Dab1 at the protein level. The localization of Tbr1- or Ctip2-positive neurons was normal in ADAMTS-3 KO mice at E16.5 (Fig. 4F). The localization of Brn1-positive neurons was indistinguishable between WT and ADAMTS-3 KO mice (Fig. 4G). Therefore, ADAMTS-3 is dispensable for neuronal migration and layer formation in the embryonic stages. 
A

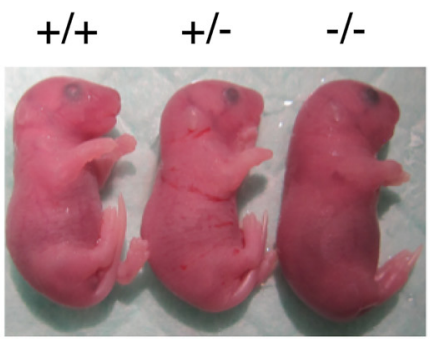

B
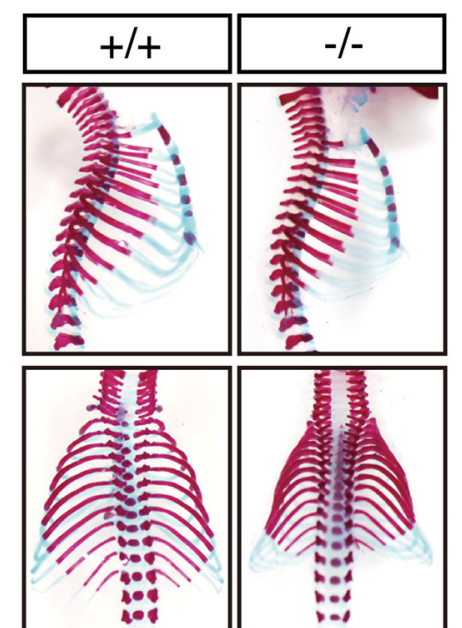

C

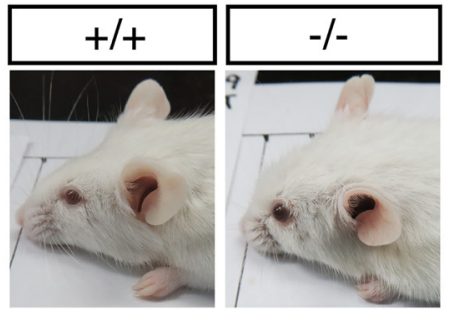

D

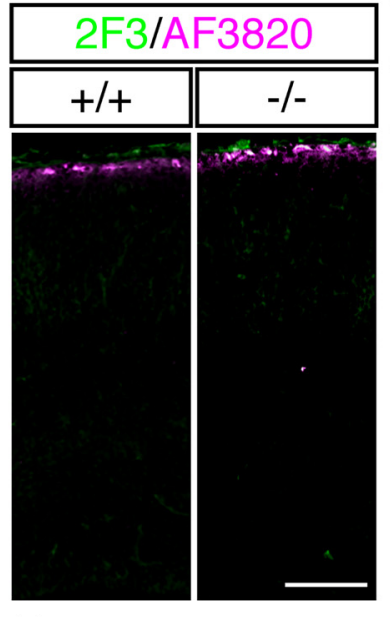

F

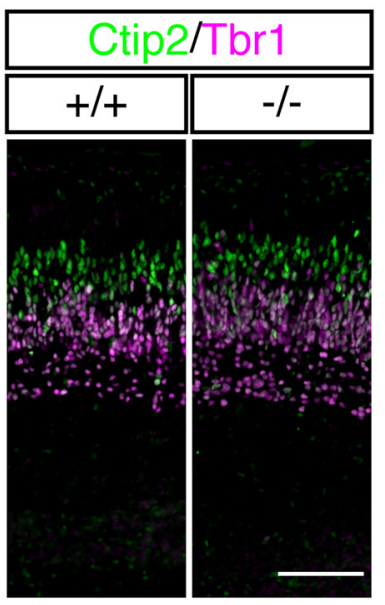

E

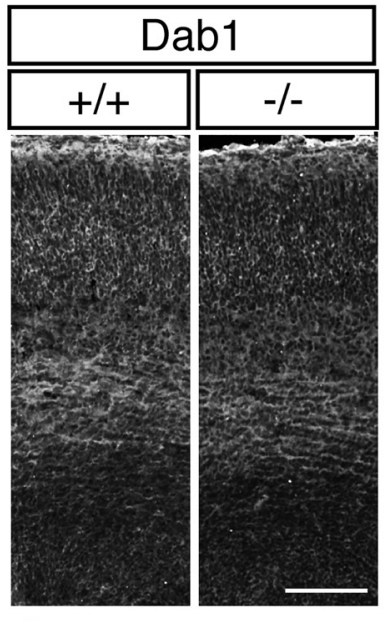

G

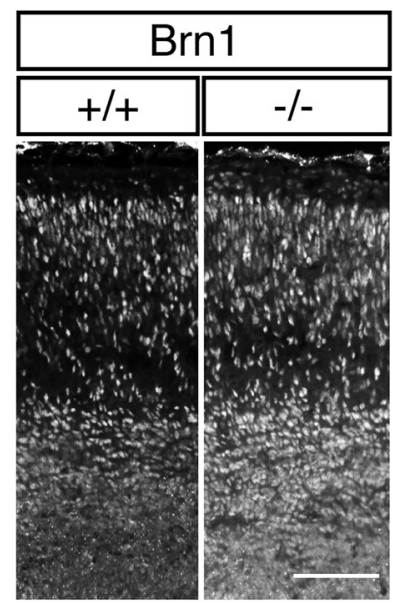

Figure 4. Phenotypes of ADAMTS-3 KO mice. A, Typical appearance of WT (left), ADAMTS-3 heterozygote (middle), and ADAMTS-3 KO (right) mice after cesarean section at E18.5. Most neonatal ADAMTS-3 KO mice exhibited cyanosis and died within 30 min after cesarean section. $\boldsymbol{B}$, Alcian blue/Alizarin red staining of WT and ADAMTS-3-K0 mice at E18.5. ADAMTS-3 K0 mice (right) show narrow rib arrangements that probably resulted in an abnormal respiratory system. $C$, The head shape of surviving ADAMTS-3 KO mice was abnormal. The surviving ratio of ADAMTS-3 KO mice was $\sim 10 \%$ on the ICR background, and even lower ( $<5 \%$ ) on the C57BL6 background. Calculating the exact percentages was impossible because dead neonates were often cannibalized. $\mathbf{D}-\mathbf{G}$, The brain structure of ADAMTS-3 K0 mice is normal. $\boldsymbol{D}, \boldsymbol{E}$, Immunohistochemical analysis for 2F3 and AF3820 (D) and Dab1 (E) at E16.5. Localization of these proteins did not differ between WT and ADAMTS-3 K0 mice. 2F3, Reelin protein without N-t cleavage (Koie et al., 2014); AF3820, N-terminal region of Reelin protein. F, G, Immunohistochemical analysis for layer markers Ctip2 and Tbr1 $(\boldsymbol{F})$ and Brn1 (G) at E16.5. Scale bars, $100 \mu \mathrm{m}$.

ADAMTS-3 contributes to the N-t cleavage and downregulation of Reelin in the postnatal cerebral cortex and hippocampus

To investigate the role of ADAMTS-3 in the postnatal forebrain, we had to circumvent the perinatal death. For this purpose, we thus established $\mathrm{cKO}$ mice in which ADAMTS-3 was deficient only in excitatory neurons of the forebrain (Fig. $5 A$ ) by using Emx1-Cre mice (Iwasato et al., 2004). In the ADAMTS-3 cKO mice, very little ADAMTS-3 mRNA was detected in the cerebral cortex and hippocampus (Fig. 5D), whereas a larger amount of ADAMTS-3 mRNA was detected in cerebellar Purkinje cells (Fig. $5 E)$. ADAMTS-3 cKO mice survived to adulthood without obvious abnormalities. The level of the NR2 fragments was decreased in the cerebral cortex of ADAMTS-3 cKO mice at P7 (Fig. 5F; Table 1) and P28 (Fig. 5H; Table 1). The amount of Dab1 was decreased in the cerebral cortex of the ADAMTS-3 cKO mice at P7 (Fig. 5F; Table 1). At P28, the amount of Dab1 tended to be decreased, but the difference was not statistically significant (Fig. $5 H$; Table 1). In the postnatal hippocampus, NR2 fragment and Dab1 levels were decreased at P7 (Fig. 5G; Table 1) and at P28
(Fig. 5I; Table 1). Therefore, ADAMTS-3 is mainly secreted from excitatory neurons and contributes to Reelin downregulation in the postnatal cerebral cortex and hippocampus.

ADAMTS-3 deficiency in excitatory neurons increases dendritic growth and branching in the postnatal cerebral cortex

Reelin positively regulates the dendritic growth and branching in excitatory neurons (Niu et al., 2004; Jossin and Goffinet, 2007; Matsuki et al., 2010; Kohno et al., 2015; O’Dell et al., 2015). Thus, we investigated neuronal morphology in the cerebral cortex of ADAMTS-3 cKO mice using Golgi-Cox staining (Fig. 6A-D). We focused on the layer V neurons because both ADAMTS-3 and Reelin were expressed in the deep layers of the cerebral cortex and their characteristic morphology made quantification relatively easy. The number (Fig. $6 E$ ) and total length (Fig. $6 F$ ) of the secondary dendrites of layer $V$ neurons were augmented in ADAMTS-3 cKO mice. These observations suggest that ADAMTS-3 deficiency enhances Reelin activity and thereby induces dendritic growth and branching in the postnatal cerebral cortex. 
A ADAMTS-3 KO
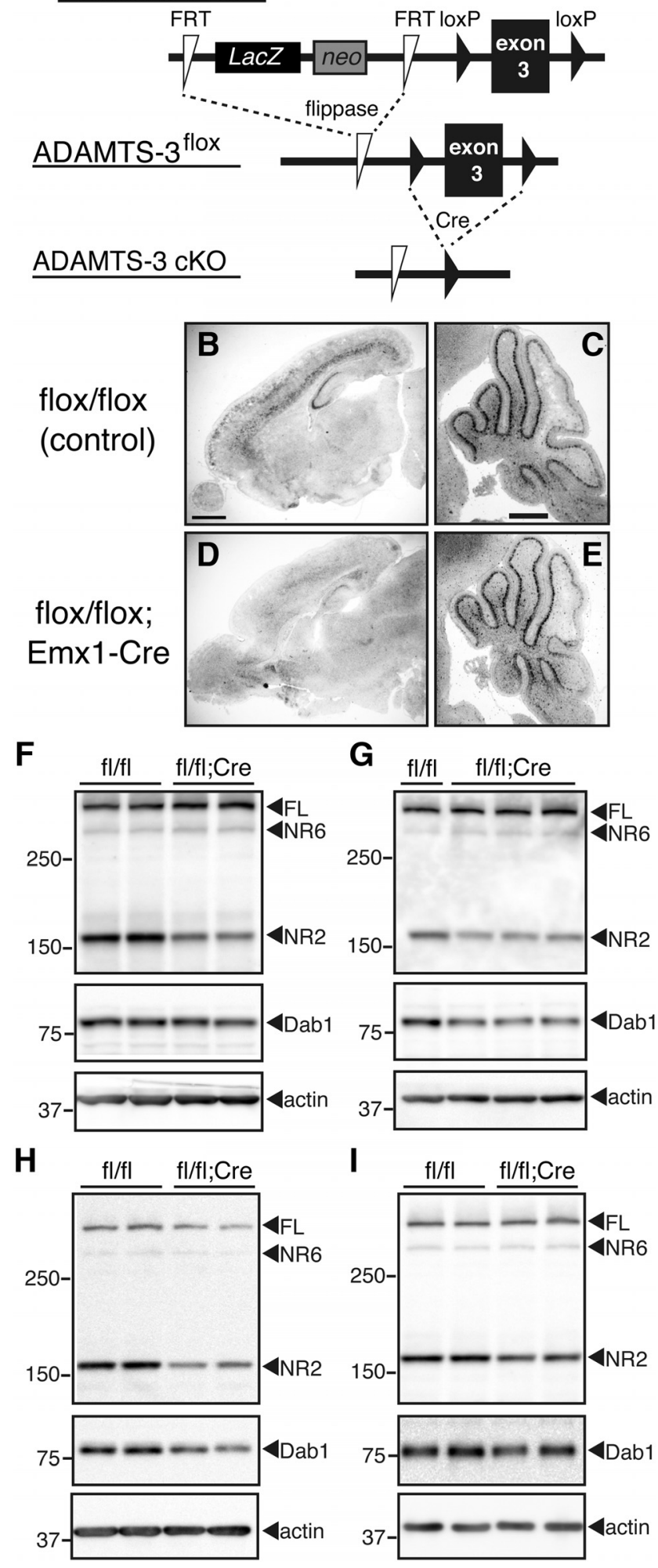

Figure 5. Reelin NR2 fragment and Dab1 levels are decreased in ADAMTS-3 cKO mice. $\boldsymbol{A}$, Diagram of ADAMTS-3-targeted alleles and production of ADAMTS-3 CKO mice. $\boldsymbol{B}-\boldsymbol{E}$, Expression of ADAMTS-3 in ADAMTS-3 CKO mice. In situ hybridization was performed using sections from ADAMTS-3 ${ }^{\text {flox/flox }}(B, C)$ or ADAMTS-3 CKO $(D, E)$ mice at P7. Please note that signals were greatly diminished in the forebrain of ADAMTS-3 CKO mice $(\boldsymbol{D})$, whereas they were maintained in the cerebellum of the same mice $(\boldsymbol{E})$. Scale bars, $1 \mathrm{~mm}$. $\boldsymbol{F}-\boldsymbol{I}$, Western blotting analysis of the cerebral cortex $(\boldsymbol{F}, \boldsymbol{H})$ and hippocampus $(\boldsymbol{G}, \boldsymbol{I})$ from ADAMTS-3 ${ }^{\text {flox/flox }}(\mathrm{fl} / \mathrm{fl})$ and ADAMTS-3 cKO (fl/fl; (re) mice at P7 $(\boldsymbol{F}, \boldsymbol{G})$ and P28 $(\boldsymbol{H}, \boldsymbol{I})$ using anti-Reelin (top), anti-Dab1 (middle), and anti-actin (bottom) antibodies.

\section{Discussion}

In the present study, we have identified ADAMTS- 3 as the major enzyme that cleaves the $\mathrm{N}$-t site of Reelin in the cerebral cortex and hippocampus. This is the first molecular identification of the enzyme that negatively regulates Reelin in vivo.

We used a classic approach to identify the protease that mediates the N-t cleavage of Reelin: protein purification from the CS of cerebral cortical neurons (Fig. 1B-D). We first investigated the optimal culture conditions for the use of CS as the starting material. Notably, separating certain proteins in the B27 supplement from $\mathrm{N}$ - $t$ cleavage activity can be difficult with column chromatography. Therefore, we replaced the culture medium with a medium containing very low B27 supplement concentrations the day after plating. These methods enabled the identification of ADAMTS-3.

The ADAMTS family consists of 19 secreted zinc metalloproteinases and shares several distinct modules, including a prodomain, a metalloproteinase domain, a disintegrin-like domain, and a thrombospondin type 1 motif (Apte, 2009; Dubail and Apte, 2015). ADAMTS-3 can cleave procollagen II, pro-vascular endothelial cell growth factor-C, fibronectin, and others (Bekhouche et al., 2016). ADAMTS-3 preferably cleaves Pro-Gly and Pro-Ala bonds (Bekhouche et al., 2016), and the sequence of the Reelin N-t site is Pro-Ala (Koie et al., 2014). These facts strongly support the hypothesis that ADAMTS-3 directly mediates $\mathrm{N}-\mathrm{t}$ cleavage. The domain structure of ADAMTS-3 is almost identical to that of ADAMTS-2 and -14, and these three molecules compose the subfamily of ADAMTS family members called procollagen N-proteinases (Bekhouche et al., 2016). The NR2 fragment level in the brain of ADAMTS-3 KO or cKO mice was greatly decreased when compared with control mice (Figs. 3, 5), but the fragment was still present at low levels, indicating the presence of other proteases that can mediate $\mathrm{N}$-t cleavage. In addition to ADAMTS-4 (Hisanaga et al., 2012; Krstic et al., 2012) and ADAMTS-5 (Krstic et al., 2012), ADAMTS-2 and -14 are likely candidate proteases. Thus, their contributions to $\mathrm{N}-\mathrm{t}$ cleavage should be investigated; however, the substrate specificity of these molecules differs from that of ADAMTS-3 (Bekhouche et al., 2016). Notably, the culture supernatant of primary cultured neurons from ADAMTS-3 KO mice had no Reelin-cleaving activity (Fig. $1 H$ ); therefore, the residual activity may be mediated by a protease(s) secreted from non-neuronal cells or by intracellular proteases (Koie et al., 2014).

ADAMTS-3 KO mice were born, but the majority died perinatally (Fig. 4). Inconsistent with our results, Janssen et al. (2016)reported the lethality of ADAMTS-3 KO embryos at approximately E15. The reason for this discrepancy is unknown but may be attributable to the difference in the introduced mutation. Janssen's group removed exons $8-10$, which encode the metalloproteinase domain. ADAMTS-3 mRNA lacking this region was detected in their KO mice (Janssen et al., 2016). However, whether the corresponding protein is present in their $\mathrm{KO}$ mice remains unknown. Our mice harbor a large insertion between exons 2 and 3 (Fig. 5A), and no ADAMTS-3 mRNA was detected (Fig. $2 F$ ). Thus, a truncated ADAMTS-3 protein may be expressed in their $\mathrm{KO}$ mice and exert a harmful effect on embryonic development. It should be mentioned that the defects of lymphatic development reported by Janssen's group was reproduced in an independent study (Bui et al., 2016) that used the same mouse line as our study. We also noted the skin edema of embryonic ADAMTS-3 mice, as shown in the previous studies (Bui et al., 2016; Janssen et al., 2016). Therefore, at least the phenotype of 
Table 1. Quantification of the amount of full-length Reelin, NR2 fragment, and Dab1 in postnatal ADAMTS-3 cK0 mice

\begin{tabular}{|c|c|c|c|c|c|c|}
\hline \multirow{2}{*}{ 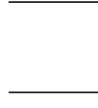 } & \multicolumn{3}{|l|}{ P7 } & \multicolumn{3}{|l|}{ P28 } \\
\hline & Average \pm SEM & $p$ value & Significance & Average \pm SEM & $p$ value & Significance \\
\hline \multicolumn{7}{|c|}{ Cerebral cortex } \\
\hline $\mathrm{FL}$ & $1.098 \pm 0.0721$ & 0.407 & N.S. & $1.08 \pm 0.249$ & 0.752 & N.S. \\
\hline NR2 & $0.390 \pm 0.0617$ & 0.0008 & $* * *$ & $0.683 \pm 0.0928$ & 0.0189 & * \\
\hline Dab1 & $0.704 \pm 0.0681$ & 0.0058 & $* *$ & $0.791 \pm 0.148$ & 0.217 & N.S. \\
\hline \multicolumn{7}{|c|}{ Hippocampus } \\
\hline $\mathrm{FL}$ & $1.258 \pm 0.181$ & 0.228 & N.S. & $0.972 \pm 0.122$ & 0.5573 & N.S. \\
\hline NR2 & $0.485 \pm 0.0614$ & 0.0011 & $* *$ & $0.736 \pm 0.0906$ & 0.0341 & * \\
\hline Dab1 & $0.666 \pm 0.0632$ & 0.0062 & ** & $0.728 \pm 0.110$ & 0.0405 & * \\
\hline
\end{tabular}

Averages are the mean of the amounts of the indicated protein compared with those of WT mice. Significance was analyzed using one sample $t$ test $(\mathrm{P} 7, n=5 ; \mathrm{P} 28, n=6) .{ }^{*} p<0.05 ;{ }^{* *} p<0.01$; ${ }^{* * *} p<0.001$.
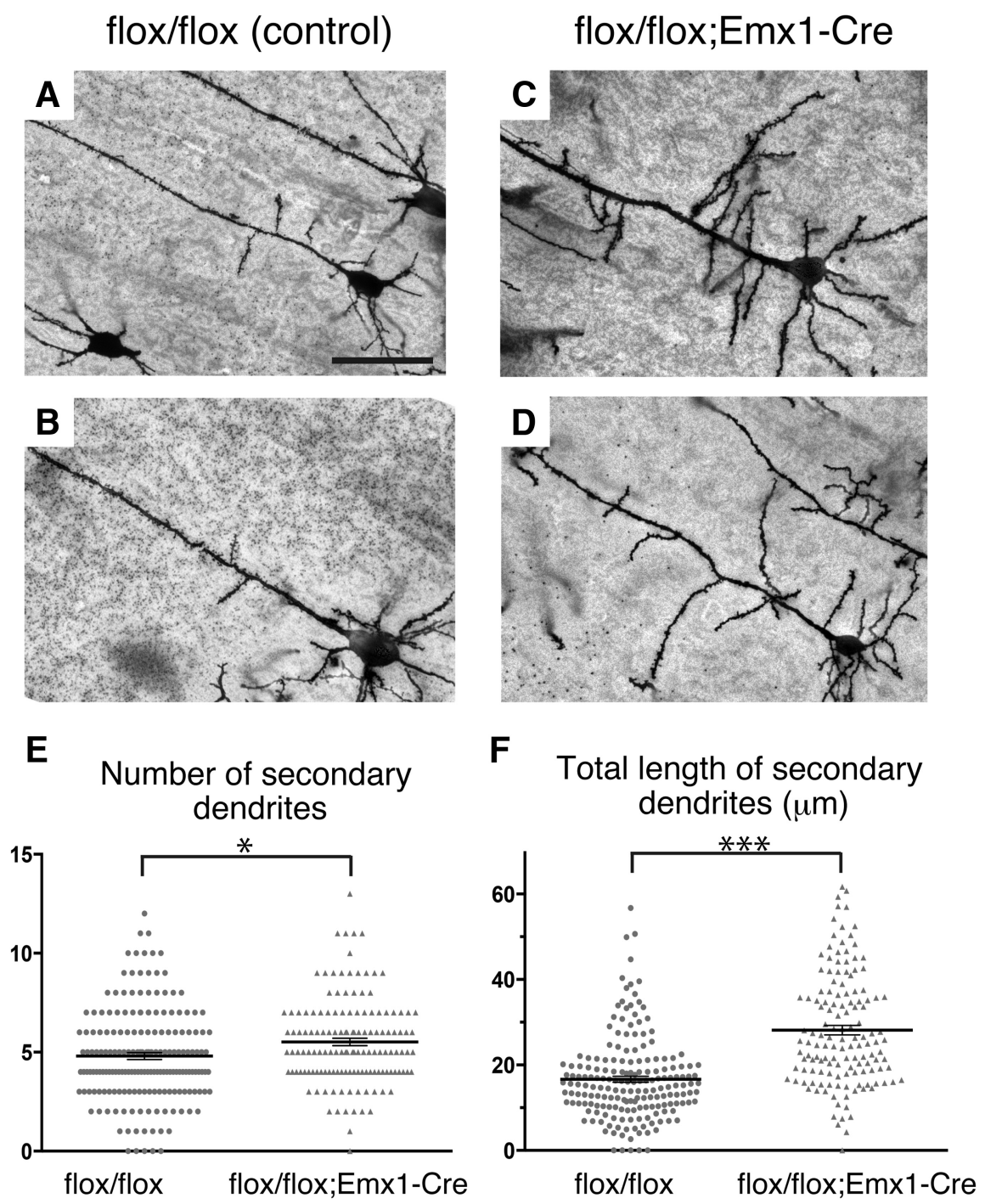

Figure 6. The dendrites of layer $V$ neurons in ADAMTS-3 CKO mice showed increased branching and elongation. $\boldsymbol{A}-\boldsymbol{D}$, Golgistained layer V neurons in the somatosensory cortex of control $(\boldsymbol{A}, \boldsymbol{B})$ and ADAMTS-3 CKO (C, D ) mice at P14. Scale bar, $50 \mu \mathrm{m}$. $\boldsymbol{E}$, The number of the secondary dendrites that were branched from the primary dendrite within $80 \mu \mathrm{m}$ of the soma. $\boldsymbol{F}$, The total length of the secondary dendrites. The cell numbers analyzed were 186 and 140 for ADAMTS- $3{ }^{\text {flox/flox }}$ and ADAMTS-3 cKO mice from four independent littermates, respectively. The data are shown as the mean \pm SEM and were analyzed using Student's $t$ test. ${ }^{*} p<$ $0.05 ;{ }^{* * *} p<0.001$.

the lymphatic development is not dependent on the KO strategy or genetic background of the mice. Neither the lethality nor postnatal phenotype was described by Bui et al. (2016).

ADAMTS-3 is expressed in the developing brain (Le Goff et al., 2006), but a detailed analysis regarding the localization of
ADAMTS-3 has not been performed. In this study, we found that ADAMTS-3 was mainly expressed in neurons that are considered a target of Reelin (Fig. 2C,D). ADAMTS-3 was mainly expressed by Tbr1-positive excitatory neurons in the developing cerebral cortex (Fig. 2G-J), whereas Reelin was expressed in CajalRetzius cells located in the most superficial layer. Thus, ADAMTS-3-expressing cells in the cerebral cortex gradually became distant from the Reelin-expressing Cajal-Retzius cells as the cerebral cortex developed. This may explain why the difference in NR2 fragment levels between WT and ADAMTS-3 $\mathrm{KO}$ mice was less apparent in the later stages of development.

A few studies have suggested that $\mathrm{N}-\mathrm{t}$ cleavage liberates the active central fragment (R36) from inactive (or reservoir) fulllength Reelin. For example, the addition of a matrix metalloproteinase inhibitor to cerebral cortical slice cultures inhibits N-t cleavage and neuronal cell migration, suggesting that $\mathrm{N}$-t cleavage is necessary for neuronal cell migration (Jossin et al., 2007). Tinnes et al. (2013) reported that maintenance of the granule cell layer of the dentate gyrus requires Reelin fragments generated by $\mathrm{N}-\mathrm{t}$ cleavage and that blocking $\mathrm{N}$-t cleavage leads to the dispersion of granule cells. They also speculated that $\mathrm{N}$-t cleavage activates Reelin. In this study, we showed that ADAMTS-3 deficiency led to a decrease in Dab1 protein, indicating that Reelin signaling was globally augmented. We also found that ADAMTS-3 deficiency did not lead to abnormal neuronal migration (Fig. 4). Therefore, N-t cleavage by ADAMTS-3 negatively regulates Reelin but is not required for the regulation of neuronal movement. We emphasize that these questions require further study because N-t cleavage is not completely abolished in ADAMTS-3 KO mice. The identification of other enzymes that mediate $\mathrm{N}$-t cleavage is necessary.

ADAMTS-3 is continuously expressed and contributes to Reelin downregulation in the cerebral cortex and hippocampus in postnatal stages (Fig. 5). Several previous reports indicated that Reelin has positive effects on dendrite formation and growth 
(Niu et al., 2004; Jossin and Goffinet, 2007; Matsuki et al., 2010; Kohno et al., 2015; O'Dell et al., 2015). Particularly, we recently reported that Reelin protein with an intact C-terminal region is required for proper orientation and branching of apical dendrites in the postnatal cerebral cortex by inducing Dab1 phosphorylation (Kohno et al., 2015). This phenomenon was evident in the marginal zone and superficial layers near Cajal-Retzius cells (Kohno et al., 2015). Our data in the present study suggested that $\mathrm{N}$-t cleavage by ADAMTS- 3 negatively regulates the formation of dendrites, at least in the deep layer neurons of the cerebral cortex (Fig. 6). We thus hypothesize that Reelin-Dab1 signaling was strengthened by ADAMTS-3 deficiency, which then directly affected dendritic morphology. However, the $\mathrm{N}$-terminal fragment of Reelin has a negative effect on dendritic branching (Chameau et al., 2009). Thus, a decrease in the NR2 fragment, rather than an increase in Reelin-Dab1 signaling, may contribute to the augmented branching and growth of dendrites in ADAMTS-3 cKO mice. Other substrates of ADAMTS-3 may also be involved in the regulation of dendrite morphology. We are currently working to clarify these mechanistic issues using both genetic and biochemical techniques.

Our observations also raise the possibility that an inhibitor of ADAMTS-3 may be a novel drug for treating neuropsychiatric and neurodegenerative disorders with reduced Reelin activity. It has been proposed that Reelin ameliorates Alzheimer's disease by antagonizing the toxicity of amyloid $\beta$-peptide (Pujadas et al., 2014; Lane-Donovan et al., 2015). ADAMTS-3 deficiency greatly reduces Tau phosphorylation (Fig. $3 G$ ), which is also involved in deterioration of Alzheimer's disease. Therefore, an inhibitor of ADAMTS-3 may delay the appearance of symptoms of Alzheimer's disease via more than one mechanism. These points are currently being investigated in our laboratories. Reduced Reelin activity is also involved in the pathogenesis of schizophrenia (Folsom and Fatemi, 2013). Particularly, we recently reported that knock-in mice with a deletion of the C-terminal region of Reelin showed reduced Reelin activity and schizophrenia-like symptoms, such as hyperactivity, reduced social behavior, and impaired working memory (Sakai et al., 2016). We are currently testing whether a deficiency in ADAMTS-3 improves these symptoms. These studies may provide the molecular basis to understand the contribution of Reelin and ADAMTS-3 to normal and pathological functions of the mammalian brain.

\section{References}

Apte SS (2009) A disintegrin-like and metalloprotease (reprolysin-type) with thrombospondin type 1 motif (ADAMTS) superfamily: functions and mechanisms. J Biol Chem 284:31493-31497. CrossRef Medline

Bekhouche M, Leduc C, Dupont L, Janssen L, Delolme F, Vadon-Le Goff S, Smargiasso N, Baiwir D, Mazzucchelli G, Zanella-Cleon I, Dubail J, De Pauw E, Nusgens B, Hulmes DJ, Moali C, Colige A (2016) Determination of the substrate repertoire of ADAMTS2, 3, and 14 significantly broadens their functions and identifies extracellular matrix organization and TGF-beta signaling as primary targets. FASEB J 30:1741-1756. CrossRef Medline

Bradley A, Anastassiadis K, Ayadi A, Battey JF, Bell C, Birling MC, Bottomley J, Brown SD, Bürger A, Bult CJ, Bushell W, Collins FS, Desaintes C, Doe B, Economides A, Eppig JT, Finnell RH, Fletcher C, Fray M, Frendewey D, et al. (2012) The mammalian gene function resource: the International Knockout Mouse Consortium. Mamm Genome 23:580-586. CrossRef Medline

Bui HM, Enis D, Robciuc MR, Nurmi HJ, Cohen J, Chen M, Yang Y, Dhillon V, Johnson K, Zhang H, Kirkpatrick R, Traxler E, Anisimov A, Alitalo K, Kahn ML (2016) Proteolytic activation defines distinct lymphagiogenic mechanisms for VEGFC and VEGFD. J Clin Invest 126:2167-2180. CrossRef Medline

Chameau P, Inta D, Vitalis T, Monyer H, Wadman WJ, van Hooft JA (2009)
The N-terminal region of Reelin regulates postnatal dendritic maturation of cortical pyramidal neurons. Proc Natl Acad Sci U S A 106:7227-7232. CrossRef Medline

D’Arcangelo G, Miao GG, Chen SC, Soares HD, Morgan JI, Curran T (1995) A protein related to extracellular matrix proteins deleted in the mouse mutant reeler. Nature 374:719-723. CrossRef Medline

D'Arcangelo G, Homayouni R, Keshvara L, Rice DS, Sheldon M, Curran T (1999) Reelin is a ligand for lipoprotein receptors. Neuron 24:471-479. CrossRef Medline

Datwani A, Iwasato T, Itohara S, Erzurumlu RS (2002) NMDA receptordependent pattern transfer from afferents to postsynaptic cells and dendritic differentiation in the barrel cortex. Mol Cell Neurosci 21:477-492. CrossRef Medline

Dubail J, Apte SS (2015) Insights on ADAMTS proteases and ADAMTS-like proteins from mammalian genetics. Matrix Biol 44-46:24-37. CrossRef Medline

Feng L, Allen NS, Simo S, Cooper JA (2007) Cullin 5 regulates Dab1 protein levels and neuron positioning during cortical development. Genes Dev 21:2717-2730. CrossRef Medline

Fernandes RJ, Hirohata S, Engle JM, Colige A, Cohn DH, Eyre DR, Apte SS (2001) Procollagen II amino propeptide processing by ADAMTS-3. Insights on dermatosparaxis. J Biol Chem 276:31502-31509. CrossRef Medline

Folsom TD, Fatemi SH (2013) The involvement of Reelin in neurodevelopmental disorders. Neuropharmacology 68:122-135. CrossRef Medline

Herz J, Chen Y (2006) Reelin, lipoprotein receptors and synaptic plasticity. Nat Rev Neurosci 7:850-859. CrossRef Medline

Hiesberger T, Trommsdorff M, Howell BW, Goffinet A, Mumby MC, Cooper JA, Herz J (1999) Direct binding of Reelin to VLDL receptor and ApoE receptor 2 induces tyrosine phosphorylation of disabled- 1 and modulates tau phosphorylation. Neuron 24:481-489. CrossRef Medline

Hisanaga A, Morishita S, Suzuki K, Sasaki K, Koie M, Kohno T, Hattori M (2012) A disintegrin and metalloproteinase with thrombospondin motifs 4 (ADAMTS-4) cleaves Reelin in an isoform-dependent manner. FEBS Lett 586:3349-3353. CrossRef Medline

Howell BW, Hawkes R, Soriano P, Cooper JA (1997) Neuronal position in the developing brain is regulated by mouse disabled-1. Nature 389:733737. CrossRef Medline

Howell BW, Herrick TM, Cooper JA (1999) Reelin-induced tryosine phosphorylation of disabled 1 during neuronal positioning. Genes Dev 13: 643-648. CrossRef Medline

Iwasato T, Nomura R, Ando R, Ikeda T, Tanaka M, Itohara S (2004) Dorsal telencephalon-specific expression of Cre recombinase in PAC transgenic mice. Genesis 38:130-138. CrossRef Medline

Janssen L, Dupont L, Bekhouche M, Noel A, Leduc C, Voz M, Peers B, Cataldo D, Apte SS, Dubail J, Colige A (2016) ADAMTS3 activity is mandatory for embryonic lymphangiogenesis and regulates placental angiogenesis. Angiogenesis 19:53-65. CrossRef Medline

Jossin Y, Goffinet AM (2007) Reelin signals through phosphatidylinositol 3-kinase and Akt to control cortical development and through mTor to regulate dendritic growth. Mol Cell Biol 27:7113-7124. CrossRef Medline

Jossin Y, Gui L, Goffinet AM (2007) Processing of Reelin by embryonic neurons is important for function in tissue but not in dissociated cultured neurons. J Neurosci 27:4243-4252. CrossRef Medline

Kohno S, Kohno T, Nakano Y, Suzuki K, Ishii M, Tagami H, Baba A, Hattori M (2009) Mechanism and significance of specific proteolytic cleavage of Reelin. Biochem Biophys Res Commun 380:93-97. CrossRef Medline

Kohno T, Honda T, Kubo K, Nakano Y, Tsuchiya A, Murakami T, Banno H, Nakajima K, Hattori M (2015) Importance of reelin C-terminal region in the development and maintenance of the postnatal cerebral cortex and its regulation by specific proteolysis. J Neurosci 35:4776-4787. CrossRef Medline

Koie M, Okumura K, Hisanaga A, Kamei T, Sasaki K, Deng M, Baba A, Kohno T, Hattori M (2014) Cleavage within Reelin repeat 3 regulates the duration and range of the signaling activity of Reelin protein. J Biol Chem 289:12922-12930. CrossRef Medline

Krstic D, Rodriguez M, Knuesel I (2012) Regulated proteolytic processing of Reelin through interplay of tissue plasminogen activator (tPA), ADAMTS-4, ADAMTS-5, and their modulators. PLoS One 7:e47793. CrossRef Medline

Krstic D, Pfister S, Notter T, Knuesel I (2013) Decisive role of Reelin signal- 
ing during early stages of Alzheimer's disease. Neuroscience 246:108116. CrossRef Medline

Lambert de Rouvroit C, de Bergeyck V, Cortvrindt C, Bar I, Eeckhout Y, Goffinet AM (1999) Reelin, the extracellular matrix protein deficient in reeler mutant mice, is processed by a metalloproteinase. Exp Neurol 156: 214-217. CrossRef Medline

Lane-Donovan C, Philips GT, Wasser CR, Durakoglugil MS, Masiulis I, Upadhaya A, Pohlkamp T, Coskun C, Kotti T, Steller L, Hammer RE, Frotscher M, Bock HH, Herz J (2015) Reelin protects against amyloid beta toxicity in vivo. Sci Signal 8:ra67. CrossRef Medline

Le Goff C, Somerville RP, Kesteloot F, Powell K, Birk DE, Colige AC, Apte SS (2006) Regulation of procollagen amino-propeptide processing during mouse embryogenesis by specialization of homologous ADAMTS proteases: insights on collagen biosynthesis and dermatosparaxis. Development 133:1587-1596. CrossRef Medline

Matsuki T, Matthews RT, Cooper JA, van der Brug MP, Cookson MR, Hardy JA, Olson EC, Howell BW (2010) Reelin and Stk25 have opposing roles in neuronal polarization and dendritic Golgi deployment. Cell 143:826836. CrossRef Medline

Miyaki S, Sato T, Inoue A, Otsuki S, Ito Y, Yokoyama S, Kato Y, Takemoto F, Nakasa T, Yamashita S, Takada S, Lotz MK, Ueno-Kudo H, Asahara H (2010) MicroRNA-140 plays dual roles in both cartilage development and homeostasis. Genes Dev 24:1173-1185. CrossRef Medline

Nakano Y, Kohno T, Hibi T, Kohno S, Baba A, Mikoshiba K, Nakajima K, Hattori M (2007) The extremely conserved C-terminal region of Reelin is not necessary for secretion but is required for efficient activation of downstream signaling. J Biol Chem 282:20544-20552. CrossRef Medline

Niu S, Renfro A, Quattrocchi CC, Sheldon M, D’Arcangelo G (2004) Reelin promotes hippocampal dendrite development through the VLDLR/ ApoER2-Dab1 pathway. Neuron 41:71-84. CrossRef Medline

O'Dell RS, Cameron DA, Zipfel WR, Olson EC (2015) Reelin prevents apical neurite retraction during terminal translocation and dendrite initiation. J Neurosci 35:10659-10674. CrossRef Medline

Pujadas L, Rossi D, Andres R, Teixeira CM, Serra-Vidal B, Parcerisas A, Maldonado R, Giralt E, Carulla N, Soriano E (2014) Reelin delays amyloid-beta fibril formation and rescues cognitive deficits in a model of Alzheimer's disease. Nat Commun 5:3443. CrossRef Medline

Rogers JT, Zhao L, Trotter JH, Rusiana I, Peters MM, Li Q, Donaldson E,
Banko JL, Keenoy KE, Rebeck GW, Hoe HS, D’Arcangelo G, Weeber EJ (2013) Reelin supplementation recovers sensorimotor gating, synaptic plasticity and associative learning deficits in the heterozygous reeler mouse. J Pychopharmacol 27:386-395. CrossRef Medline

Sakai K, Shoji H, Kohno T, Miyakawa T, Hattori M (2016) Mice that lack the C-terminal region of Reelin exhibit behavioral abnormalities related to neuropsychiatric disorders. Sci Rep 6:28636. CrossRef Medline

Sato Y, Kobayashi D, Kohno T, Kidani Y, Prox J, Becker-Pauly C, Hattori M (2016) Determination of cleavage site of Reelin between its sixth and seventh repeat and contribution of meprin metalloproteases to the cleavage. J Biochem 159:305-312. CrossRef Medline

Sekine K, Kubo K, Nakajima K (2014) How does Reelin control neuronal migration and layer formation in the developing mammalian neocortex? Neurosci Res 86:50-58. CrossRef Medline

Skarnes WC, Rosen B, West AP, Koutsourakis M, Bushell W, Iyer V, Mujica AO, Thomas M, Harrow J, Cox T, Jackson D, Severin J, Biggs P, Fu J, Nefedov M, de Jong PJ, Stewart AF, Bradley A (2011) A conditional knockout resource for the genome-wide study of mouse gene function. Nature 474:337-342. CrossRef Medline

Stranahan AM, Erion JR, Wosiski-Kuhn M (2013) Reelin signaling in development, maintenance, and plasticity of neural networks. Ageing Res Rev 12:815-822. CrossRef Medline

Teixeira CM, Martín ED, SahúnI, Masachs N, Pujadas L, Corvelo A, Bosch C, Rossi D, Martinez A, Maldonado R, Dierssen M, Soriano E (2011) Overexpression of Reelin prevents the manifestation of behavioral phenotypes related to schizophrenia and bipolar disorder. Neuropsychopharmacology 36:2395-2405. CrossRef Medline

Tinnes S, Ringwald J, Haas CA (2013) TIMP-1 inhibits the proteolytic processing of Reelin in experimental epilepsy. FASEB J 27:2542-2552. CrossRef Medline

Trotter JH, Lussier AL, Psilos KE, Mahoney HL, Sponaugle AE, Hoe HS, Rebeck GW, Weeber EJ (2014) Extracellular proteolysis of Reelin by tissue plasminogen activator following synaptic potentiation. Neuroscience 274:299-307. CrossRef Medline

Uchida T, Baba A, Pérez-Martínez FJ, Hibi T, Miyata T, Luque JM, Nakajima K, Hattori M (2009) Downregulation of functional Reelin receptors in projection neurons implies that primary Reelin action occurs at early/ premigratory stages. J Neurosci 29:10653-10662. CrossRef Medline 